\title{
lobenguane I-124
}

National Cancer Institute

\section{Source}

National Cancer Institute. Iobenguane I-124. NCI Thesaurus. Code C101776.

A radioconjug ate composed of the positron-emitting radioisotope iodine I 124 labeled to iobenguane, the synthetic aralkylguanidine analogue of the neurotransmitter norepinephrine (NE), with potential diagnostic imaging applications upon positron emitting tomography (PET) or computed tomography (CT). Upon administration, iobenguane I-124 is taken up and accumulates in the granules of adrenal medullary chromaffin cells and in the pre-synaptic granules of adrenergic neurons in a manner almost identical with that of NE. In turn, tumor cells can be imaged upon PET or CT . 